(2) CrossMark

Cite this: RSC Adv., 2015, 5, 73323

Received 29th July 2015

Accepted 24th August 2015

DOI: $10.1039 / c 5 r a 15131 g$

www.rsc.org/advances

\section{Polymers of intrinsic microporosity as high temperature templates for the formation of nanofibrous oxides $\uparrow$}

\author{
H. Al Kutubi, ${ }^{\text {ab }}$ L. Rassaei, ${ }^{\text {b W. }}$. Olthuis, ${ }^{c}$ G. W. Nelson, ${ }^{d}$ J. S. Foord, ${ }^{e}$ P. Holdway, ${ }^{f}$ \\ M. Carta, ${ }^{9}$ R. Malpass-Evans, ${ }^{9}$ N. B. McKeown, ${ }^{9}$ S. C. Tsang, ${ }^{\text {h }}$ R. Castaing, ${ }^{a}$ \\ T. R. Forder, ${ }^{a}$ M. D. Jones, ${ }^{a}$ D. He ${ }^{a}$ and F. Marken ${ }^{\star a}$
}

The highly rigid molecular structure of Polymers of Intrinsic Microporosity (PIM) - associated with a high thermolysis threshold combined with the possibility to fill intrinsic micropores allows the direct "one-step" templated conversion of metal nitrates into nanostructured metal oxides. This is demonstrated here with PIM-EA-TB and with PIM-1 for the conversion of $\operatorname{Pr}\left(\mathrm{NO}_{3}\right)_{3}$ to $\operatorname{Pr}_{6} \mathrm{O}_{11}$.

Nano-templating offers rapid access to novel nano-structured materials and interfaces ${ }^{\mathbf{1}}$ in particular for technologies where high surface area inorganic architectures are desirable. ${ }^{2}$ Template hosts such as regular opaloid structures, ${ }^{3}$ surfactantbased nano-structures, ${ }^{4}$ or novel MOF structures ${ }^{5}$ have been proposed. Here, polymers of intrinsic microporosity (PIM) ${ }^{6}$ are introduced as "high temperature templates" for "one-step" metal oxide nano-structure growth as demonstrated for the case of $\mathrm{Pr}_{6} \mathrm{O}_{11}$.

Polymers of intrinsic microporosity represent a novel group of polymers with a rigid backbone (see structures in Fig. 1) that prevents them from collapsing into a close-packed conformation even when heated up. Space is created within the polymer,

${ }^{a}$ Department of Chemistry, University of Bath, Claverton Down, Bath BA2 7AY, UK. E-mail:f.marken@bath.ac.uk

${ }^{b}$ Department of Chemical Engineering, Delft University of Technology, Delft, The Netherlands

'BIOS/Lab-on-a-Chip group, University of Twente, PO Box 217, 7500 Enschede, The Netherlands

${ }^{d}$ Imperial College London, Department of Materials, Royal School of Mines, Exhibition Road, London, SW7 2AZ, UK

${ }^{e}$ Chemistry Research Laboratories, Oxford University, South Parks Road, Oxford OX1 3TA, UK

${ }^{{ }_{\text {Department }}}$ of Materials, Begbroke Science Park, Sandy Lane, Yarnton, Oxford, OX5 1PF, UK

${ }^{8}$ School of Chemistry, University of Edinburgh, West Mains Road, Edinburgh, EH9 3JJ, UK

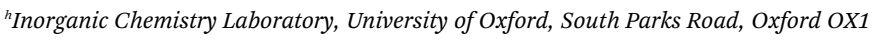
$3 Q R, U K$

$\dagger$ Electronic supplementary information (ESI) available: Additional scanning electron microscopy data and EDX data. See DOI: 10.1039/c5ra15131g allowing for permanent microporosity and leading to a surface area as high as $900 \mathrm{~m}^{2} \mathrm{~g}^{-1}$ for PIM-1 (ref. 7) and $1027 \mathrm{~m}^{2} \mathrm{~g}^{-1}$ for PIM-EA-TB. ${ }^{8}$ PIM materials are readily casted from solution into films and have been investigated for applications in gas separation membranes, catalysis, and gas storage. ${ }^{9}$ From thermogravimetric data (TGA, see Fig. 1) it is clear that these rigid polymer structures also show considerable high temperature stability (after some initial weight loss due to water desorption below $100{ }^{\circ} \mathrm{C}$, decomposition onset occurs for PIM-EA-TB at $310^{\circ} \mathrm{C}$ and for PIM-1 at $480{ }^{\circ} \mathrm{C}$, both with charring). Therefore, in this study we contrast the ability of PIM-EA-TB and PIM-1 to function as template hosts for high temperature metal oxide nanostructure synthesis. A suitable model nano-structured metal oxide with promise for application in sensors ${ }^{\mathbf{1 0}}$ and in catalysis ${ }^{11}$ is $\operatorname{Pr}_{6} \mathrm{O}_{11}$.

The synthesis of praseodymium oxides has been carried out previously by chemical vapour deposition, ${ }^{12}$ calcination of praseodymium hydroxide $\left(\mathrm{Pr}(\mathrm{OH})_{3}\right),{ }^{\mathbf{1 3 , 1 4}}$ electro-deposition, ${ }^{15}$ or by thermal transformation of a praseodymium-containing precursor compound. ${ }^{\mathbf{1 6}}$ The products obtained through

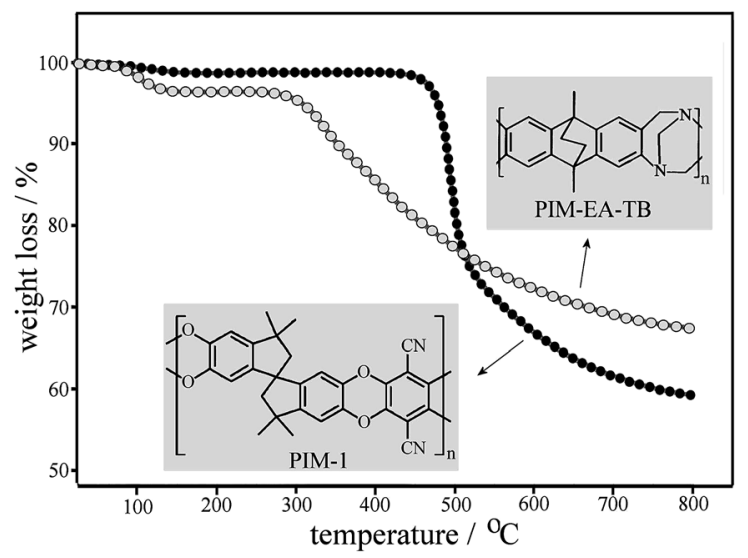

Fig. 1 Thermogravimetric data and molecular structures for PIM-EATB and PIM-1. 
thermal oxidation depend on both the precursor as well as oxidation conditions such as temperature and oxygen partial pressure. The oxygen deficient $\operatorname{Pr}_{6} \mathrm{O}_{11}$ phase can be formed as dominant phase at temperatures higher than $465{ }^{\circ} \mathrm{C} .{ }^{17}$ Bäumer and coworkers ${ }^{11 b}$ investigated the formation of nanostructured praseodymium oxide via thermal decomposition of praseodymium nitrate with and without carbon-based templates. Here, we report the formation of praseodymium oxide structures not in bulk, but directly at the surface of tin-doped indium oxide (ITO) electrodes.

When the PIM host solution ( $1 \mathrm{mg} \mathrm{mL} \mathrm{m}^{-1}$ in chloroform) and $\operatorname{Pr}\left(\mathrm{NO}_{3}\right)_{3}$ solution $\left(1 \mathrm{mg} \mathrm{mL}{ }^{-1}\right.$ in DMF) are mixed in $1: 1$ weight ratio and deposited onto ITO, calcination at $500{ }^{\circ} \mathrm{C}$ in air affords a thin film of oxide materials on ITO (see Experimental, Fig. 2).

The presence of praseodymium oxide is confirmed by EDX (see Fig. S1D $\dagger$ ) and by XRD (Fig. 2E, with characteristic lines $\left.{ }^{\mathbf{1 5}, \mathbf{1 1 b}}\right)$. Electron micrographs show fibrous deposits of $\operatorname{Pr}_{6} \mathrm{O}_{11}$ on the ITO substrate (Fig. 2). With PIM-EA-TB as host template "leaf-like" nano-structures are seen. Doubling the amount of precursor deposit resulted in slightly courser structures, which must reflect the pore geometry of the precursor at the point when solidification of the oxide precursor occurs. Changing the ratio of PIM-EA-TB to $\operatorname{Pr}\left(\mathrm{NO}_{3}\right)_{3}$ resulted in similar structures (see Fig. S1A-C $\dagger$ ). When investigating the PIM-1 template (see Fig. 2C and D) it became apparent that a much finer nano-structure with filaments down to $20 \mathrm{~nm}$ or less are formed. BET-based pore size data for PIM-EA-TB polymer (12-
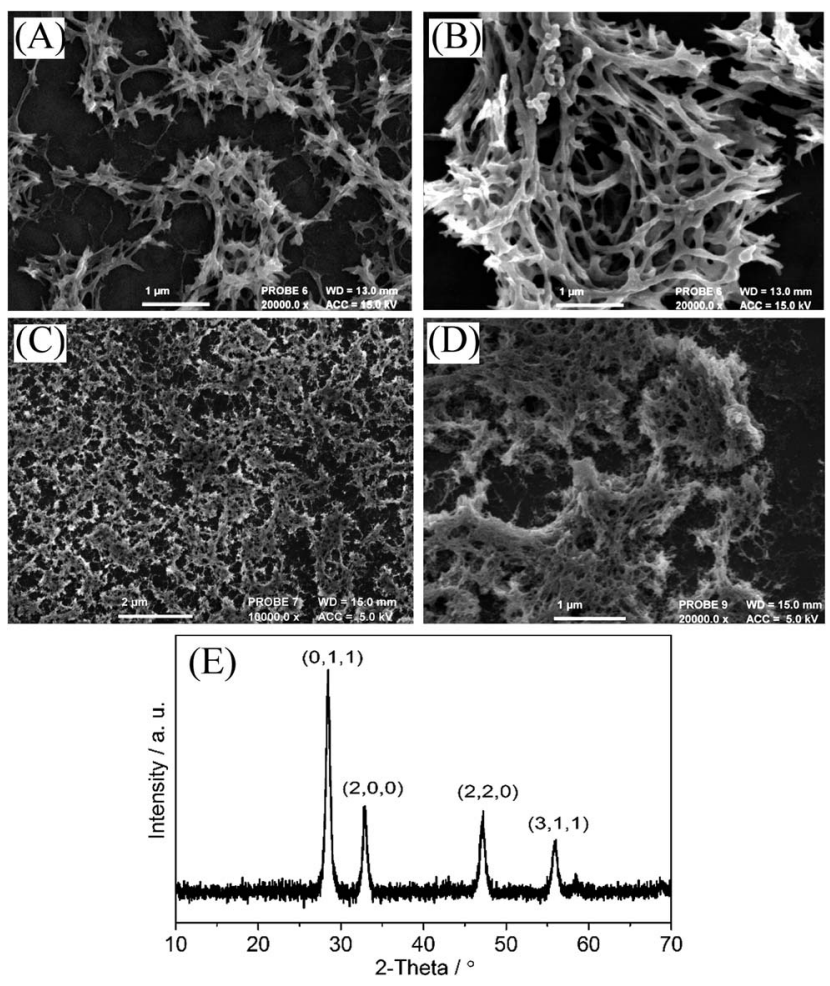

Fig. 2 Electron micrographs of (A) a 10-layer PIM-EA-TB - $\operatorname{Pr}\left(\mathrm{NO}_{3}\right)_{3}$ $(1: 1)$ film after calcination, (B) a 20 -layer PIM-EA-TB - $\operatorname{Pr}\left(\mathrm{NO}_{3}\right)_{3}(1: 1)$ film after calcination, (C) a 10-layer PIM-1 - $\operatorname{Pr}\left(\mathrm{NO}_{3}\right)_{3}(1: 1)$ film after calcination and (D) a higher resolution image of the same sample. (E) XRD analysis.
$40 \AA$ A (ref. 18)) and for PIM-1 polymer (5 to $15 \AA$ A (ref. 19)) suggest that in both the parent polymers only comparably smaller pores are present. The feature size in the $\operatorname{Pr}_{6} \mathrm{O}_{11}$ deposits appear considerably bigger for PIM-EA-TB but more similar to the original pore size for PIM-1. Therefore the feature size could be linked to the behaviour of the polymer template at elevated temperature. TGA data in Fig. 1 clearly show the higher thermal stability of PIM-1, which is likely to result in a finer oxide nanostructure that more closely reflects the original PIM-1 template pores.

In order to demonstrate the absence of polymer remnants, further surface analysis has been performed with XPS (Fig. 3). Apart from the underlying ITO surface elements clear evidence for Pr, C, and O is observed in the survey scan. Carbon signals are very low and assigned to adventitious surface-adsorbed molecules (or possibly remnants of the template). Oxygen signals are assigned predominantly to $\operatorname{Pr}_{6} \mathrm{O}_{11}$, but with some other species present at the surface. Wolffram et $a .^{20}$ have studied thin $\operatorname{Pr}_{x} \mathrm{O}_{y}$ films made from $\operatorname{Pr}_{6} \mathrm{O}_{11}$ targets and their work is the primary basis for fitting the O1s spectra here. Four peaks were required to curve fit the O1s spectra. The two main component at $\approx 528.5 \mathrm{eV}$ and $\approx 531 \mathrm{eV}$ most likely belong to $\operatorname{Pr}_{2} \mathrm{O}_{3}$ and $\operatorname{Pr}_{6} \mathrm{O}_{11}$, respectively. Lutkehoff et al. ${ }^{21}$ indicated that the signal at $\approx 532 \mathrm{eV}$ can be ascribed to Pr-based hydroxides, such as $\operatorname{Pr}(\mathrm{OH})_{3}$. These would be expected from the breakdown of $\operatorname{Pr}_{6} \mathrm{O}_{11}$ in the presence of surface water (eventually leading to $\mathrm{PrO}_{2}$ formation). ${ }^{20}$ The feature at $\approx 529.5 \mathrm{eV}$ could be either indicative of the presence of $\mathrm{PrO}_{2}$ (ref. 22) or be related to surface adsorbates in the form of Pr-O-R; ${ }^{20}$ both species have O1s signal known to overlap with the $\operatorname{Pr}_{6} \mathrm{O}_{11}$ O1s signal. As seen in Table 1, the $\operatorname{Pr}_{6} \mathrm{O}_{11}$ and Pr-hydroxide content at surfaces seem
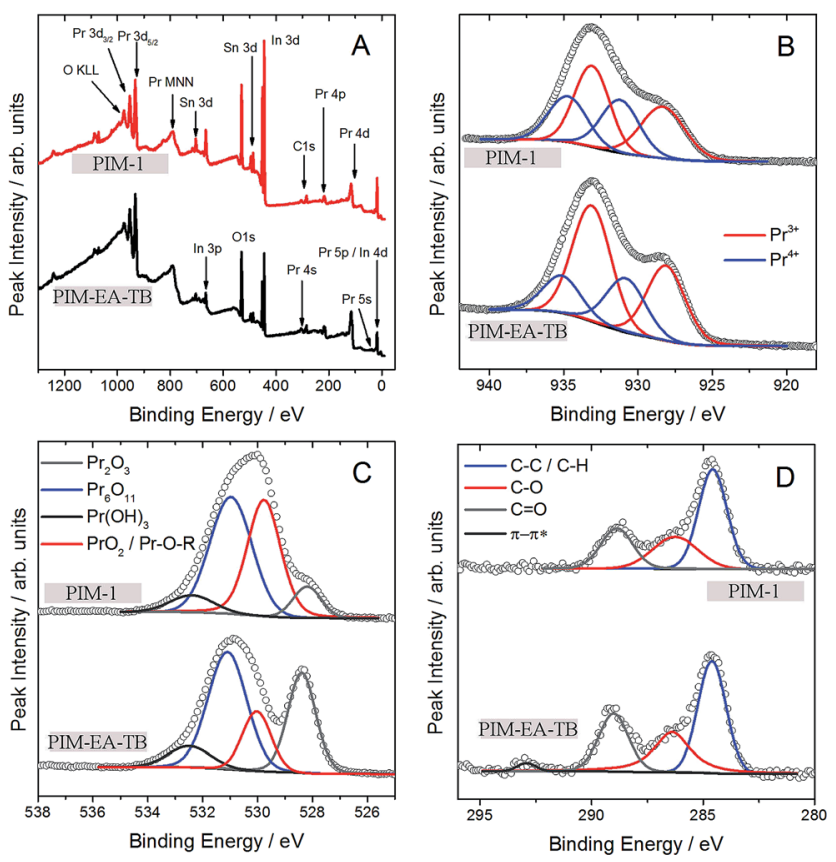

Fig. 3 XPS survey spectra (A) of PIM-EA-TB and PIM-1 and core level data for (B) $\mathrm{Pr}_{3} \mathrm{~d}_{5 / 2}$ (with red and blue curve fits for $\mathrm{Pr}^{3+}$ and $\mathrm{Pr}^{4+}$ species, respectively), (C) O1s, (D) C1s. 
Table 1 Oxygen composition data from XPS in as-prepared $\mathrm{Pr}_{6} \mathrm{O}_{11}$

\begin{tabular}{llr}
\hline & \multicolumn{2}{c}{ \% O1s composition } \\
\cline { 2 - 3 } Species & PIM-EA-TB & PIM-1 \\
\hline $\mathrm{Pr}_{2} \mathrm{O}_{3}$ & 29.2 & 8.2 \\
$\mathrm{PrO}_{2} /$ adsorbates & 16.7 & 39.2 \\
$\mathrm{Pr}_{6} \mathrm{O}_{11}$ & 45.3 & 45.8 \\
Hydroxides & 8.8 & 6.9
\end{tabular}

independent of the method of preparation. However, use of PIM-EA-TB favours the additional formation of $\mathrm{Pr}_{2} \mathrm{O}_{3}\left(\mathrm{Pr}^{3+}\right)$, whilst use of PIM-1 favours the formation of $\mathrm{PrO}_{2}\left(\mathrm{Pr}^{4+}\right)$ and surface adsorbates. The chemical reasons for this difference are currently not fully understood.

Wolffram et al..$^{20}$ note that unambiguous fitting of the Pr3d core levels is difficult and remains controversial. Again using the above reference as a model, four chemical environments were curve fitted. The line pair at higher binding energy $\left(\approx 931 \mathrm{eV}\right.$ and $\approx 935 \mathrm{eV}$ ) are ascribed to $\operatorname{Pr}^{4+}$ species (e.g. $\operatorname{Pr}_{6} \mathrm{O}_{11}$ and $\mathrm{PrO}_{2}$ ). Assuming that they reflect chemical environments at the surface and are not satellites. ${ }^{20}$ The line pair at lower binding energy $(\approx 928 \mathrm{eV}$ and $\approx 933 \mathrm{eV})$ originate from $\operatorname{Pr}^{3+}($ e.g. $\mathrm{Pr}_{2} \mathrm{O}_{3}$ and $\left.\operatorname{Pr}(\mathrm{OH})_{3}\right)$. The ratio between $\operatorname{Pr}^{3+}: \mathrm{Pr}^{4+}$ species is approximately $2: 1$ and $4: 3$ for PIM-EA-TB and PIM-1, respectively. Notwithstanding the different chemical states, the surface $\mathrm{O} / \mathrm{Pr}$ ratio is 4.6 and 2.6 for PIM-EA-TB and PIM-1, respectively. These ratios are quite high - the stoichiometric and expected $\mathrm{O} / \mathrm{Pr}$ ratio for $\mathrm{Pr}_{2} \mathrm{O}_{3}\left(\operatorname{Pr}^{3+}\right)$ and $\operatorname{Pr}_{6} \mathrm{O}_{11}\left(\mathrm{Pr}^{4+}\right)$ is 1.5 and 1.8, respectively. This may indicate that the $\mathrm{O} 1 \mathrm{~s}$ signal is influenced by other sources of surface oxygen, other than the Proxides (e.g. hydroxides, water, the underlying substrate, etc.). One expects an $\mathrm{O} / \mathrm{Pr}$ ratio $<2: 1$ for the Pr-based oxides. ${ }^{20}$ It is clear from Table 2 that PIM-EA-TB has a higher $\mathrm{Pr}^{3+}$ component than PIM-1, and vice versa in the case of the $\mathrm{Pr}^{4+}$ species. In future, bulk elemental analytical methods have to be employed to further investigate bulk phase purity and possible impurities from the thermolysis process in the resulting products as a function of thermolysis time and temperature.

Electrochemical testing of $\mathrm{Pr}_{6} \mathrm{O}_{11}$ nano-structures was performed in aqueous $0.1 \mathrm{M} \mathrm{KNO}_{3}$ (Fig. 4). Nyquist plots (Fig. 4A) and Bode plots (not shown) suggest a high frequency switch from resistive to capacitive behaviour associated with the ITO substrate time constant (for bare ITO $110 \Omega \times 15 \mu \mathrm{F}=1.65 \mathrm{~ms}$, Fig. 4D). With $\operatorname{Pr}_{6} \mathrm{O}_{11}$ films deposited an additional resistive component, $R_{\mathrm{et}}$, is observed associated with charging of the

Table $2 \mathrm{Pr}^{3+} / \mathrm{Pr}^{4+}$ composition data from XPS in as-prepared $\mathrm{Pr}_{6} \mathrm{O}_{11}$

\begin{tabular}{|c|c|c|c|c|c|c|}
\hline & \multicolumn{4}{|c|}{$\begin{array}{l}\text { Pr3d } d_{5 / 2} \text { binding } \\
\text { energy }(\mathrm{eV})\end{array}$} & \multicolumn{2}{|c|}{$\begin{array}{l}\text { Pr3d } \\
\text { composition } \\
(\%) \\
\end{array}$} \\
\hline & 928 & 931 & 933 & 935 & $\operatorname{Pr}^{3+}$ & $\operatorname{Pr}^{4+}$ \\
\hline PIM-EA-TB & 27.0 & 19.2 & 39.8 & 14.0 & 66.8 & 33.2 \\
\hline PIM-1 & 25.9 & 23.1 & 31.5 & 19.5 & 57.4 & 42.6 \\
\hline
\end{tabular}

nano-structured deposit. The impedance for this charging decreases from a calcined 10-layer PIM-EA-TB - $\operatorname{Pr}\left(\mathrm{NO}_{3}\right)_{3}$ deposit to calcined 20-layer PIM-EA-TB - $\operatorname{Pr}\left(\mathrm{NO}_{3}\right)_{3}$ and again to calcined 10-layer PIM-1 - $\operatorname{Pr}\left(\mathrm{NO}_{3}\right)_{3}$. This result indicates an increase in oxide surface area in this sequence.

Complementary cyclic voltammetry data (Fig. 4B) also demonstrate the decrease in impedance as an increase in charging current. Full charging and therefore full capacitive characteristics would require more time (or a higher conductivity of the oxide). The electrochemical properties are consistent with those reported previously for $\mathrm{Pr}_{6} \mathrm{O}_{11}$ with potential applications in charge storage and sensing. However, the methodology for oxide nano-structure formation in PIM templates will be applicable for a much wider range of oxides and mixed oxides.

\section{Experimental}

\section{Chemical reagents}

Praseodymium nitrate hexa-hydrate, $N, N$-dimethylformamide (DMF) and chloroform were obtained from Sigma-Aldrich and used without further purification. Polymers with intrinsic microporosity PIM-EA-TB ${ }^{8}$ and PIM-1 (ref. 23) were prepared following literature procedures. Tin-doped indium oxide glass plates (ITO) with a resistivity of $15 \Omega$ per square were obtained from Image Optics Components Ltd (Basildon, UK). A KCl-saturated calomel (SCE) reference electrode was obtained from radiometer.

\section{Instrumentation}

The morphology of the samples was analysed using a JEOL FESEM6301F field emission scanning electron microscopy (FE- 
SEM). XPS experiments were conducted using a Thermo K Alpha (Thermo Scientific) spectrometer (operating at $\approx 10^{-8}-10^{-9}$ Torr) with a $180^{\circ}$ double focusing hemispherical analyser running in constant analyser energy (CAE) mode and a 128channel detector. A mono-chromated $\mathrm{Al} \mathrm{K \alpha}$ radiation source (1486.7 eV) was used. Peak fitting was conducted using XPS Peak Fit (v. 4.1) software using Shirley background subtraction. Peaks were referenced to the adventitious carbon C1s peak $(284.6 \mathrm{eV})$ and peak areas were normalized to the photoelectron cross-section of the F1s photoelectron signal using atomic sensitivity factors. ${ }^{24}$ An Elite Thermal Systems Ltd tube furnace was used to remove the possible organic contamination on the ITO electrodes and for calcination of metal oxides. Electrochemical testing was performed using an Ecochemie Autolab PGSTAT12 potentiostat system. TGA data were collected on a Setaram Setsys Evolution TGA instrument. The samples were heated under Ar from $20{ }^{\circ} \mathrm{C}$ until $800{ }^{\circ} \mathrm{C}$ at $10 \mathrm{~K}$ per minute.

\section{Procedure for nano- $\operatorname{Pr}_{6} \mathrm{O}_{11}$ film deposition}

Tin-doped indium oxide (ITO) coated glass slides were cut into $1 \mathrm{~cm} \times 3 \mathrm{~cm}$ strips and cleaned by rinsing with water and ethanol, followed by calcination at $500{ }^{\circ} \mathrm{C}$ for one hour. A solution of $1 \mathrm{mg} \mathrm{mL} \mathrm{m}^{-1} \mathrm{PIM}$ in chloroform was mixed with a solution of $1 \mathrm{mg} \mathrm{mL}{ }^{-1} \operatorname{Pr}\left(\mathrm{NO}_{3}\right)_{3} \cdot 6 \mathrm{H}_{2} \mathrm{O}$ in DMF in the desired ratio. From the resulting mixture, $25 \mu \mathrm{L}$ was deposited onto a clean ITO plate covering approximately $1 \mathrm{~cm}^{2}$ and dried in an oven at $100{ }^{\circ} \mathrm{C}$ for 15 minutes. This deposition process was repeated for a desired number of layers and finally followed by calcination in a tube furnace at $500{ }^{\circ} \mathrm{C}$ for 1 hour.

\section{Conclusions}

Praseodymium oxide nano-structures have been formed in a convenient and novel "one-step" process using a high temperature template based on polymers of intrinsic microporosity. The resulting structures differ from those obtained through simple calcination and show a leaf-like or nano-fibrous structures. Finer structures are formed with the more thermally stable PIM-1 template. The results indicate that this methodology could be used beneficially for the rapid formation of a wider range of nano-structured metal oxide as well as mixed metal oxides with future applications in electronic, sensor, or solar cell components.

\section{Notes and references}

1 I. W. Hamley, Nanotechnology, 2003, 14, R39.

2 P. V. Braun, P. Osenar, V. Tohver, S. B. Kennedy and S. I. Stupp, J. Am. Chem. Soc., 1999, 121, 7302.

3 A. Stein, Microporous Mesoporous Mater., 2001, 44, 227.

4 G. J. D. Soler-illia, C. Sanchez, B. Lebeau and J. Patarin, Chem. Rev., 2002, 102, 4093.
5 X. Xu, R. Cao, S. Jeong and J. Cho, Nano Lett., 2012, 12, 4988. 6 N. B. McKeown and P. M. Budd, Chem. Soc. Rev., 2006, 35, 675.

7 P. M. Budd, B. S. Ghanem, S. Makhseed, N. B. McKeown, K. J. Msayib and C. E. Tattershall, Chem. Commun., 2004, 230.

8 M. Carta, R. Malpass-Evans, M. Croad, Y. Rogan, J. C. Jansen, P. Bernardo, F. Bazzarelli and N. B. McKeown, Science, 2013, 339, 303.

9 N. B. McKeown and P. M. Budd, Macromolecules, 2010, 43, 5163.

10 (a) X. S. Liang, Y. H. He, F. M. Liu, B. Wang, T. G. Zhong, B. Quan and G. Lu, Sens. Actuators, B, 2007, 125, 544; (b) S. Shrestha, C. M. Y. Yeung, C. E. Mills, J. Lewington and S. C. Tsang, Angew. Chem., Int. Ed., 2007, 46, 3855.

11 (a) E. S. Putna, J. M. Vohs, R. J. Gorte and G. W. Graham, Catal. Lett., 1998, 54, 17; (b) Y. Borchert, P. Sonstrom, M. Wilhelm, H. Borchert and M. Bäumer, J. Phys. Chem. C, 2008, 112, 3054.

12 H. C. Aspinall, J. Gaskell, P. A. Williams, A. C. Jones, P. R. Chalker, P. A. Marshall, J. F. Bickley, L. M. Smith and G. W. Critchlow, Chem. Vap. Deposition, 2003, 9, 235.

13 X. W. Ouyang, S. S. Yuan, Q. B. Qiu, W. W. Zeng, G. A. Hope and H. H. Li, Inorg. Chem. Commun., 2014, 46, 21.

14 S. Shrestha, C. M. Y. Yeung, F. Marken, C. E. Mills and S. C. Tsang, Sens. Actuators, B, 2007, 123, 400.

15 S. Shrestha, F. Marken, J. Elliott, C. M. Y. Yeung, C. E. Mills and S. C. Tsang, J. Electrochem. Soc., 2006, 153, C517.

16 S. Zinatloo-Ajabshir and M. Salavati-Niasari, New J. Chem., 2015, 39, 3948.

17 G. A. M. Hussein, B. A. A. Balboul, M. A. A. Warith and A. G. M. Othman, Thermochim. Acta, 2001, 369, 59.

18 E. Madrid, Y. Y. Rong, M. Carta, N. B. McKeown, R. MalpassEvans, G. A. Attard, T. J. Clarke, S. H. Taylor, Y. T. Long and F. Marken, Angew. Chem., Int. Ed., 2014, 53, 10751.

19 M. Heuchel, D. Fritsch, P. M. Budd, N. B. McKeown and D. Hofmann, J. Membr. Sci., 2008, 318, 84.

20 D. Wolffram, M. Ratzke, M. Kappa, M. J. Montenegro, M. Döbeli, Th. Lippert and J. Reif, J. Mater. Sci. Eng. B, 2004, 109, 24.

21 S. Lutkehoff, M. Neumann and A. Slebarski, Phys. Rev. B: Condens. Matter Mater. Phys., 1995, 52, 13808.

22 M. Sawangphruk and J. S. Foord, Diamond Relat. Mater., 2010, 19, 885.

23 (a) P. M. Budd, K. J. Msayib, C. E. Tattershall, B. S. Ghanem, K. J. Reynolds, N. B. McKeown and D. Fritsch, J. Membr. Sci., 2005, 251, 263; (b) P. M. Budd, E. S. Elabas, B. S. Ghanem, S. Makhseed, N. B. McKeown, K. J. Msayib, C. E. Tattershall and D. Wang, Adv. Mater., 2004, 16, 456.

24 C. D. Wagner, L. E. Davis, M. V. Zeller, J. A. Taylor, R. M. Raymond and L. H. Gale, Surf. Interface Anal., 1981, 3, 211 . 